\title{
Morphological analysis of pollen grains from heterodynamous stamens of some Aeschynomene L. (Leguminosae: Papilionoideae - Dalbergieae)
}

\author{
- Higor Antonio-Domingues $^{1,2,4}$, Angela Maria da Silva Corrêa ${ }^{2}$, Monica Lanzoni Rossi $^{3}$, \\ Adriana Pinheiro Martinelli ${ }^{3}$ and Cynthia Fernandes Pinto da $\mathrm{Luz}^{2}$
}

Received: 4.05.2018; accepted: 21.08.2018

\begin{abstract}
Morphological analysis of pollen grains from heterodynamous stamens of some Aeschynomene L. (Leguminosae - Papilionoideae - Dalbergieae)). Flowers with heterodynamous stamens can present differences in the pollen grains of each stamen size group. Species of_Aeschynomene L. present didynamous stamens (five long and five short) but little is known about their pollen dimorphism. The objective of this study was to increase the knowledge about the pollen characteristics in Aeschynomene and emphasize the possible morphological differences between the pollen grains of long and short stamens in order to contribute to ecological and taxonomic studies. Pollen grains from the two groups of stamens size of ten species were analyzed separately, according to the standard methodology for studies of pollen morphology. In addition, analyses of variance, comparison of means and base index were performed. The results showed that the amb, shape, endoaperture type and sexine ornamentation did not vary in the pollen grains of the long and short stamens in the same specimen, but they varied among the species. However, in relation to the size of the pollen grains of the two groups of stamens, four species presented significant differences regarding the size of the polar and equatorial axes. The pollen morphological data obtained considering the heteromorphism of the stamens can contribute to the knowledge of the reproductive dynamics of the genus, and to the systematic studies.
\end{abstract}

Keywords: Fabaceae, heteromorphism, Dalbergia subclade, Palynology, pollen morphology

RESUMO - (Análise morfológica dos grãos de pólen de estames heterodínamos de algumas Aeschynomene L. (Leguminosae: Papilionoideae - Dalbergieae)). Flores que apresentam androceu com estames de alturas diferentes (heterodínamos) podem também apresentar características distintas entre os grãos de pólen em cada tamanho de estame. As espécies de Aeschynomene L. apresentam estames didínamos (cinco longos e cinco curtos), mas até o momento pouco se sabe sobre o dimorfismo polínico. Diante da carência de estudos palinológicos do gênero, o objetivo do presente trabalho foi de incrementar o conhecimento sobre as características polínicas do gênero Aeschynomene L., enfatizando as possíveis diferenças morfológicas entre os grãos de pólen dos grupos de estames longos e curtos, contribuindo com os estudos ecológicos e taxonômicos. Os grãos de pólen dos dois grupos de tamanho de estames de 10 espécies foram analisados separadamente utilizando-se a metodologia padrão em morfologia polínica, além de análises de variância e de comparação da média e índice de base. Os resultados inéditos mostraram que as características de âmbito, forma, tipo de endoabertura e ornamentação da sexina não variaram entre os grãos de pólen dos estames longos e curtos num mesmo espécime, mas sim entre as espécies. No entanto, com relação ao tamanho dos grãos de pólen dos dois grupos de estames, quatro espécies apresentaram diferenças significativas quanto ao tamanho dos eixos polar e equatorial. Os dados morfopolínicos adquiridos com relação ao heteromorfismo dos estames podem contribuir para o conhecimento da dinâmica reprodutiva do gênero e para os estudos sistemáticos.

Palavras-chave: Fabaceae, heteromorfismo, morfologia polínica, Palinologia, subclado Dalbergia

\section{Introduction}

The tribe Dalbergieae sensu latu Klitgaard and Lavin (2005) in Papilionoideae subfamily of
Fabaceae comprises 49 genera, wich Aeschynomene L. as the third most representative of the tribe. The Aeschynomene genus presents pantropical distributions, with approximately 180 species in the

1. Instituto de Botânica, Programa de Pós-Graduação em Biodiversidade Vegetal e Meio Ambiente, Avenida Miguel Stéfano, 3687, 04301-902 São Paulo, SP, Brasil

2. Instituto de Botânica, Núcleo de Pesquisa em Palinologia, Avenida Miguel Stéfano, 3687, 04301-902 São Paulo, SP, Brasil

3. Universidade de São Paulo, Centro de Energia Nuclear na Agricultura, Laboratório de Histopatologia e Biologia Estrutural de Plantas, Avenida Centenário, 303, 13400-970 Piracicaba, SP, Brasil

4. Corresponding author: higor.domingues@hotmail.com 
world (Rudd 1981, Lewis et al. 2005). Brazil is a centre of diversity, with 49 accepted species, from which 26 are endemic (Lima et al. 2015). The genus' habit varies from herbaceous to shrubby and is divided into two sections and nine series (Rudd 1955, 1959, Fernandes 1996). However, the combined analysis by Ribeiro et al. (2007) and others (Lavin et al. 2011) demonstrated the paraphyly of genus. Aeschynomene presents papilionoid corolla, which is related to the co-evolution between the hymenopterans and the Papilionoideae (Arroyo 1981, Judd et al. 2007), whose flowers' androecium has heterodynamous stamens (five long and five short) and uniform anthers (Rudd 1955). Tucker (1996) studied many species of Leguminosae and pointed out that stamens with dimorphisms are commonly found in this family, possibly differing in size, filament length, anther shape and moment of dehiscence. The presence of different stamen sizes was diagnosed in Aeschynomene in research carried out by Burkart (1939), Fernandes (1996), Sampaio (2005), Silva \& Antunes (2014).

Carvalho \& Oliveira (2003) found significant differences in the pollen grains-dimensions among heteromorphic anthers of Senna sylvestris (Vell.) H.S. Irwin \& Barneby (Leguminosae) and Luo et al. (2008) describe differences in sexine ornamentation among long and short stamens of the same specimen of Melastoma malabathricum L. (Melastomataceae).

It is also known that polymorphism occurs in the size of the pollen grain of longistylous and brevistylous flowers (Furtado et al. 2014), in the number of apertures (Stanski et al. 2016) and sexine ornamentation of Psychotria capitata (Ruiz \& Pav.) (Rubiaceae) (Ganders 1976, Stanski et al. unpublished data). These characters that change depending on the floral morphology, such as the number and aperture type and sexine ornamentation are important in the delimitation of pollen types in ecological and palynotaxonomic studies (Salgado-Labouriau 1973, Lorscheitter 2006).

There are studies available concerning pollen morphology of Aeschynomene, such as Sharma (1968), Ohashi (1971), Salgado-Labouriau (1973), Pire (1974), Mitra and Mondal (1982), von der Ohe and Dustmann (1996), Souza et al. (2004), Buril et al. (2011) and Antonio-Domingues et al. (2015, 2016a, 2016b). However, these authors did not describe the pollen grains separately from long and short stamens.

Studies on genus concerning the morphological differences between pollen grains from heterodynamous groups of stamens are inexistent. In this context, the aim of this research was to carry out an unprecedented analysis of the pollen morphology of ten species from the genus Aeschynomene L.; with attention to the possible morphological differences between long and short stamens of the same specimen to contribute to the studies of reproductive biology, pollination and taxonomy to the genus.

\section{Materials and methods}

Flower buds were collected from herbarium specimens of ten Aeschynomene L.: Aeschynomene americana L.: BRAZIL. SÃo PAULO: São Paulo, Anel Viário, 27-II-2015, Shirasuma RT 4032 (SP488201). Aeschynomene brevipes Benth.: BRAZIL. MATO Grosso: Pontes e Lacerda, 18-IV-2012, Borges L.M. \& Oliveira CT 757 (RB608259). Aeschynomene denticulata Rudd.: BRAZIL. Mato Grosso Do Sul: Porto Mourinho, Rodovia Bonito, 14-XI-2002, Hatschbach M. et al. 74233 (MBM276632). Aeschynomene elaphroxylon (Gillies \& Perrr.) Taub.: BRAZIL. Rio DE JANEIRO: Rio de Janeiro, Jardim Botânico do Rio de Janeiro, 20-XIII-1984 Faria S.M. \& Lima H.C. 119 (RB335688). Aeschynomene fluminensis Vell.: BRAZIL. Mato Grosso do Sul: Campo Grande, Anel Viário, 14-XIII-2001, Lima L.C.P. et al. 105 (SP367488). Aeschynomene martii Benth.: BRAZIL. BAHIA: Livramento do Brumado, 25-III-1991, Lewis G.P. \& Andrade A.S.M.M. 1972 (MBM147346). Aeschynomene montevidensis Vogel: BRAZIL. PARANÁ: Guaíra, Parque Nacional de Sete Quedas, 18-III-1982, Melo M.M.R.F. 328 (SP209299). Aeschynomene rudis Benth.: BRAZIL. MARANHÃO: Viana, 23-VII-1919, Carvalho O. 3 (SP3427). Aeschynomene selloi Vogel.: ARGENTINA. BuENOS AIres: Belgramo Bajo, 10-I-1931, Burkart A. 3630 (SP28105). Aeschynomene sensitiva Sw.: BRAZIL. PAranÁ: Paranaguá, Alexandra, 21-XII-1948, Tassmann G. s.n. (SP58253).

Groups with long (+) and short (-) stamens were segregated for palynological analysis. To avoid contamination between groups $(+)$ and (-) samples were dissected under stereomicroscope, with sterilized tweezers and just flowers with anthers in pre anthesis were studied. These samples were prepared according to Erdtman (1960) and Melhem et al. (2003).

For each stamen group (+) and (-) of each specimen the polar and equatorial axes in equatorial view were measured in 25 random pollen grains. The measurements of length and width of colpus and endoapertures, thickness of sexine layer 
(tectum + columelae) and nexine layer, total exine (sexine + nexine) and lumen length were based on ten pollen grains. The description of pollen morphology to the genus level followed Barth and Melhem (1988), Punt et al. (2007) and Hesse et al. (2009).

For the 25 measurements we performed the arithmetic mean (x), with the standard deviation pattern (sx), the sample deviation standard (s) and the coefficient of variation (V). The comparisons of means were performed through the analysis of confidence interval at $95 \%$ of probability (Vieira 1981), with software Minitab 14. For the ten measurements the arithmetic mean was calculated, except for lumen size at which the variation range was used.

The values of axes were subjected to variance analysis (ANOVA) and significant differences between means were identified by the Tukey test at $5 \%$ probability. The base index (BX) was calculated and consists of the subtraction of each of the 25 measurements of an axis (MS) by the smallest value of variation range (M). Classes were established: with values lower than 2.0 considered as a low value $(<2.0=\mathrm{B}-)$ and values higher than 2.0 as a high value $(>2.0=\mathrm{B}+)$. This index was described along with the sample standard deviation, coefficient of variability and the statistical difference between the stamens of the groups (+) and (-) per species, to establish a standard among the four variables.

Photomicrographs were obtained using an OLYMPUS BX 50 microscope with camera and CellSens software for Windows. For the SEM images the pollen grains were deposited in a metal stub, coated by cathodic spray (Leica EM ACE 600) using Au with thickness of $120 \mathrm{~nm}$. Samples were observed under the SEM JEOL JSM-IT300LV (Tokyo Japan) operating with $20 \mathrm{kV}$ electron beam and the images were digitized.

\section{Results and Discussion}

\section{Aeschynomene L. (figures 1-17, table 1)}

The pollen grains from the two groups of stamens of Aeschynomene presented the following characteristics: monads, small to medium sized; isopolar; amb varying from circular to triangular, shape varying from oblate to prolate; 3-colporate (figures 1-6), colpi with margin (figures 2, 7, 10-11), colpi with pointed apices (figures 4,8 ) or bifurcates and united at the pole (parasyncolporate) (figures 5, 9), with operculum (figures 1-2, 10-11), operculum presenting different patterns of ornamentation (figures 10-11). Endoaperture varying from lolongate (figure 1), to lalongate (figure 2) up to circular. Nanoreticulate, microreticulate (figure 11) to reticulate (figure 13) or rugulate (figure 12) exine; the lumens vary from $<0.50 \mu \mathrm{m}$ (nanoreticulate) to $>1.0 \mu \mathrm{m}$ (reticulate) (figure 13-15; table 1); simplicolumellate muri. Sexine thicker than the nexine (figures 3, 6, 1617).

\section{Pollen morphology of short and long stamen groups}

These characteristics (polarity, amb, apertures, ornamentarion) did not vary between the two sets of stamens, but rather between the species. The pollen grain differences among the species demonstrate that the palynological characteristics can be used in the segregation of the species with palynotaxonomic value.

Although the pollen grains of the long and short stamens are in the same size class in Aeschynomene denticulata, A. elaphroxylon, $A$. montevidensis and $A$. rudis, they present significant differences concerning the size of their polar and equatorial axes, when submitted to the analysis of variance and subsequent Tukey's test (table 1). When submitted to the same analyses, the specimens of $A$. americana, A. brevipes, A. fluminensis, A. martii, A. selloi and A. sensitiva they did not present significant differences.

Carvalho \& Oliveira (2003) report that the long anther of Senna sylvestris has the largest pollen grains when compared to those of the other short anthers. Furtado et al. (2014) demonstrated that the longistylous morpho of Psychotria capitata presented smaller pollen grains $(12.87 \pm 1.28 \mu \mathrm{m})$ than the brevistylous morpho $(18.73 \pm 0.60 \mu \mathrm{m})$. We did not observe here the pattern long stamen/largest pollen grain axes in all species. According to our study, the pollen grains of the short stamens not necessarily present low values of the axes, as in A. elaphroxylon (figures 16-17, table 1), whose pollen grains of the short stamens presented a higher mean to polar and equatorial axes of pollen grains from the long stamen group. In the case of $A$. denticulata and $A$. montevidensis, the long stamens presented the pollen grains with the largest polar axes, whereas in A. elaphroxylon and A. rudis it was the short stamens that presented the highest values for the same axis (table 1). Concerning the equatorial axis, the pollen grains from these four species, the short stamens always had the highest values.

Considering a confidence interval at $95 \%$ for the equatorial and polar axes, it can be observed that 

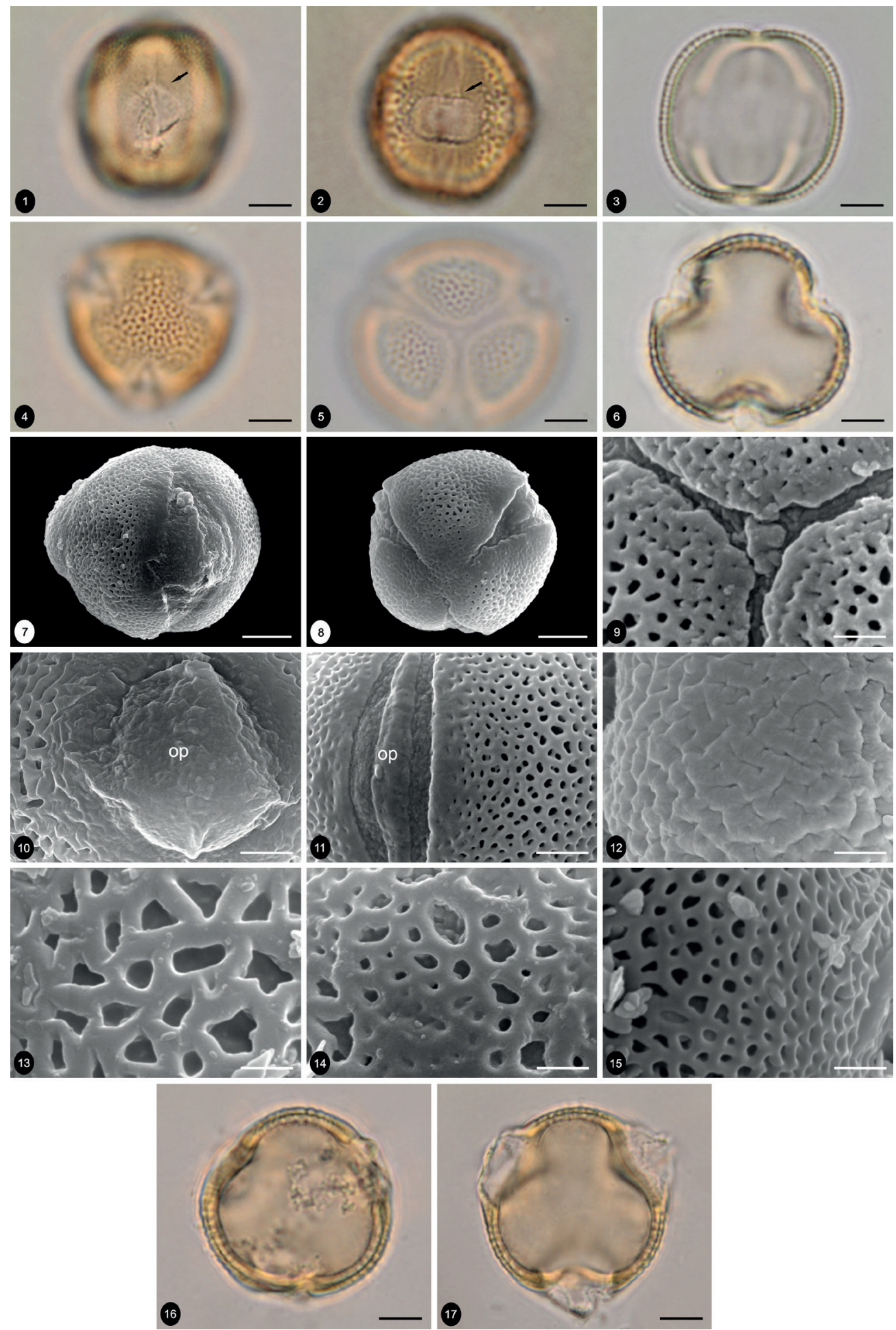

Figures 1-17. Light (1-6, 16-17) and scanning electron micrographs (7-15) of the pollen grains of Aeschynomene. 1. A. brevipes, equatorial view, detail of the operculate colpus and lolongate endoaperture. 2. A. sensitiva, equatorial view, detail of the operculate colpus and lalongate endoaperture. 3. A. americana, equatorial view, optical section. 4. A. montevidensis, polar view, normal colporus (not parasyncolpate). 5. A. americana, polar view, parasyncolpate colporus. 6. A. denticulada, polar view, optical section. 7-8. A. fluminensis. 7. equatorial view. 8. polar view, normal colporus (not parasyncolpate). 9. A. americana, polar view, parasyncolpate colporus. 10. A. elaphroxylon, equatorial view, detail of the operculum and the reticulate-microreticulate sexine. 11. A. americana, equatorial view, detail of the operculum and the nanoreticulate sexine. 12. A. brevipes, equatorial view, rugulate sexine. 13. A. martii, reticulate sexine. 14. A. selloi, nanoreticulate to reticulate sexine. 15. A. denticulata, nanoreticulate to microreticulate sexine. 16-17. A. elaphroxylon. 16. pollen grain of the long stamen. 17. pollen grain of the short stamen. Scale bar $=5 \mu \mathrm{m}(1-8,16-17) ; 1 \mu \mathrm{m}(9-15)$. 
(figures 18-19, table 1): 1) at the polar axis (figure 18), A. americana (+ -) are different from the others because presents the smallest pollen grains. From $A$. montevidensis (-) up to A. brevipes (-), was formed a continuous values group; within this group $A$. rudis $(-)$ and $A$. selloi $(+)$ presented the widest range in the confidence interval limits and largest values to coefficient of variability. From $A$. martii (+) up to $A$. fluminensis (-), another continuous values group was formed. Aeschynomene fluminensis had the highest values to polar axis. Aeschynomene martii (-) and A. elaphroxylon $(+)$ presented the widest range in the confidence interval limits and largest values to coefficient of variability. 2) at the equatorial axis (figure 19), the pollen grains formed two continuous groups with the lowest values; one smaller than $19 \mu \mathrm{m}$ from Aeschynomene sensitiva (+) up to A. rudis (+), and another one larger than $19 \mu \mathrm{m}$ from $A$. americana (-) to A. martii (+). From the larger than $19 \mu \mathrm{m}, A$. martii (-) presented the broader range in the confidence interval limits among all species. Separating from the other pollen grains, A. fluminensis $(-+)$ grouped together with intermediate values of the equatorial axis and $A$. elaphroxylon (+-) grouped together with the largest values and broadest range on the interval of confidence limits, corroborating the results pointed out by the ANOVA procedure and subsequently the Tukey's test. Aeschynomene denticulata, A. montevidensis and A. elaphroxylon, differently from A. rudis, did not separate in the confidence interval, but present significant differences.

The base index (B) demonstrated the difference of the data values between the lowest sample values

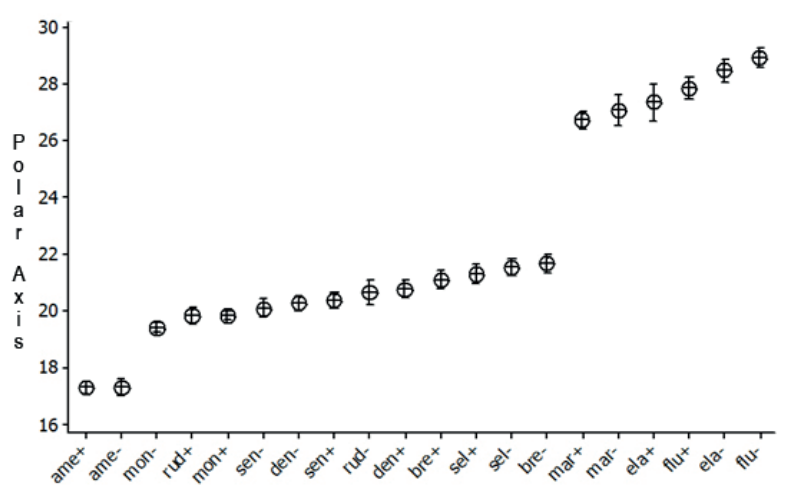

Figure 18. Representation of confidence interval of means at $95 \%$ of probability of Polar axis $(\mu \mathrm{m})$ in equatorial view of Aeschynomene pollen grains. The higher and lower boundaries show the confidence interval; the average circle shows the arithmetic mean. compared with the other values measured for each axis of the pollen grains (table 1). The highest B indexes were found in A. elaphroxylon ( $\geq 3.3$ ), followed by $A$. martii ( $\geq 2.7)$, A. brevipes $(\geq 2.2)$ and $A$. rudis $(\geq 2.2)$. In these species, the highest values for the standard deviation of the sample and for the coefficient of variation were also observed, however not all species presented significant differences between the pollen grain axis of the $(+)$ and $(-)$ stamens group (A. brevipes, A. martii). Although they have $B+$, in $A$. martii, $A$. brevipes and $A$. rudis, these values were found only in one of the axes from one of the groups of stamens, whereas the others axes were B-. The lowest B indexes were found in $A$. montevidensis $(\leq 0.7)$, followed by $A$. denticulata $(\leq 0.9)$, with significant differen between stamen group (+) and (-). It is worth mentioning that between the two groups of stamens, A. americana, presented the highest index of the basis (B), standard deviation of the sample and coefficient of variation than some species with significant differences. Therefore, it is not possible to establish a constant pattern among the four variables compared.

Concerning their axes size and the B values, the pollen grains of the long stamens of Aeschynomene denticulata, A. elaephroxylon, A. montevidensis and A. rudis presented significant differences in polar and equatorial axes when compared to the short stamens. The pollen grains of the other species studied did not present statistically significant differences in these axes. It is recommended that new statistical treatments and models be used, as well as studing more species and specimens of Aeschynomene aiming to complement the data obtained. As the pollen

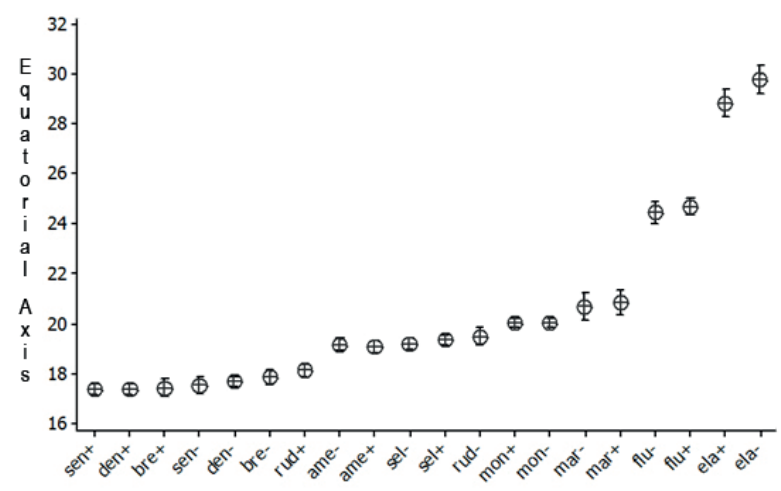

Figure 19. Representation of confidence interval of means at $95 \%$ of probability of Equatorial axis $(\mu \mathrm{m})$ in equatorial view of Aeschynomene pollen grains. The higher and lower boundaries show the confidence interval; the average circle shows the arithmetic mean. 


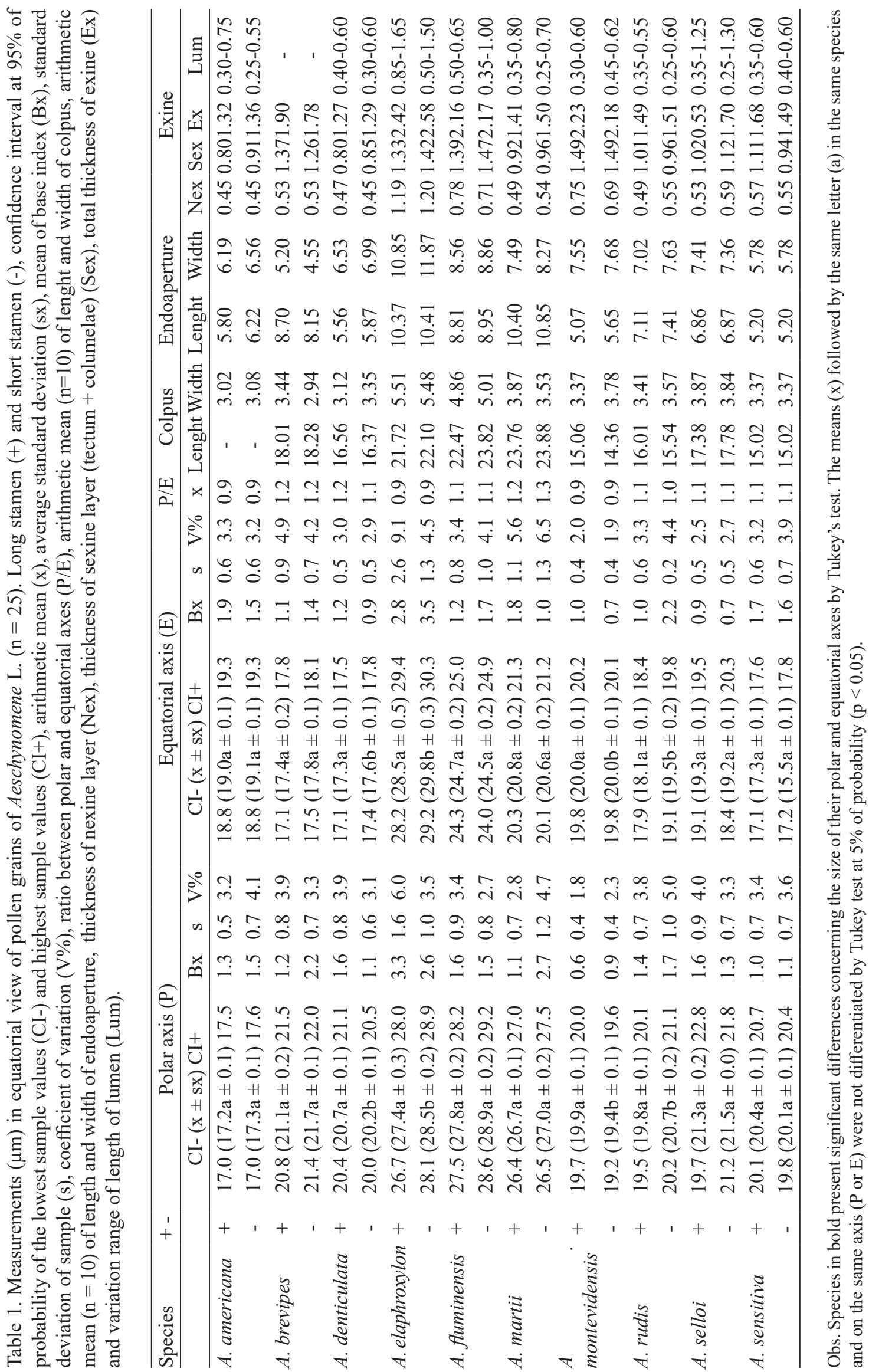


grains showed variations in the characteristics of the apertures and exine ornamentation between species the results of which are of the utmost importance for systematic studies.

\section{Acknowledgements}

We are grateful to the curators of the herbaria (SP, $\mathrm{RB}, \mathrm{MBM}$ ) who provided exsiccates (see specimens investigated). Master's degree scholarship was obtained from the Coordenação de Aperfeiçoamento de Pessoal de Nível Superior (CAPES) to the first author. The authors are thankful to the Conselho Nacional de Desenvolvimento Científico e Tecnológico (CNPq) for the fellowship of "Productivity in research" to the fifth author (Process CNPq 302766/2016-2). The authors also extend their thanks to the Me. Carin Stanski of the Postgraduate program at the Universidade Federal do Paraná who provided the MBM herbarium flower buds, also to M.Sc. Vera Lygia El Id of the Postgraduate program at the Instituto de Botânica and Dr. Cláudio José Barbedo, scientific researcher of the Instituto de Botânica, for the assistance in statistical analysis and "Núcleo de Apoio à Pesquisa em Microscopia Eletrônica Aplicada a Agricultura, Escola Superior de Agricultura "Luiz de Queiroz", Universidade de São Paulo" to SEM images.

\section{Literature cited}

Arroyo, M.T.K. 1981. Breeding systems and pollination biology in Leguminosae. In: R.M. Polhill \& P.H. Raven. (eds.). Advances in Legumes Systematics, part. 2. Royal Botanic Gardens, Kew, pp. 723-729.

Antonio-Domingues, H., Correa, A.M.S., Oliveira, M.L.A.A., Queiros, R.T. \& Luz C.F.P. 2015. Palynologycal Study of Brazilian 'Aeschynomene' L. (Fabaceae - Papilionoideae). In: A.P.F. Peres, B. Marazzi (coord.). International Symposium and Workshop Legume Morphology, Botucatu, pp. 27-28.

Antonio-Domingues, H., Correa, A.M.S., Rossi, M.L., Martinelli, A.P., Oliveira, M.L.A.A., \& Luz C.F.P. 2016a. Pollen morphology of Brazilian Aeschynomene L. series Pleuronerviae (Leguminosae - Papilionoideae). In: Anais de Congresso da $67^{\circ}$ Congresso Nacional de Botânica (LD Thomaz, pres.), SBB, Vitória.

Antonio-Domingues, H., Correa, A.M.S., Rossi, M.L., Martinelli, A.P., Oliveira, M.L.A.A., \& Luz C.F.P. 2016b. Pollen morphology of Brazilian Aeschynomene L. series Viscidulae (Leguminosae - Papilionoideae). In: Boletín de la Asociación Latinoamericana de Paleobotánica y Palinología 16: 275-276.
Barth, M.O. \& Melhem, T.S. 1988. Glossário ilustrado de Palinologia. Editora Universidade Estadual de Campinas, Campinas.

Buril, M.T., Alves, M. \& Santos, F.A.R. 2011. Tipificação polínica em Leguminosae de uma área prioritária para conservação da Caatinga: Caesalpinioideae e Papilionoideae. Acta Botanica Brasilica 25: 699-712.

Burkart, A. 1939. Estudios sistemáticos sobre las Leguminosas - Hedisareas de la República Argentina y regiones adyacentes. Darwiniana 3: 232-261.

Carreira, L.M.M., Silva, M.F., Lopes, J.R.C. \& Nascimento, L.A.S. 1996. Catálogo de Pólen das Leguminosas da Amazônia Brasileira. Belém, Museu Paraense Emílio Goeldi.

Carvalho, D.A. \& Oliveira, P. 2003. Biologia reprodutiva e polinização de Senna sylvestris (Vell.) H.S. Irwin \& Barneby (Leguminosae, Caesalpinioideae). Revista Brasileira de Botânica 26: 319-328.

Erdtman, G. 1960. The acetolysis method. A revised description. Svensk Botanisk Tidskrift 561-564.

Fernandes, A. 1996. O taxon Aeschynomene no Brasil. EUFC, Fortaleza.

Furtado, M.C., Perez-Barrales, R., Matias, R., Rodrigues, E.B. \& Consolaro, H. 2014. Fluxo de pólen: o uso do dimorfismo polínico na análise da eficiência da polinização cruzada. In: K. Agostine (org.). Anais do $1^{\circ}$ Simpósio Brasileiro de Polinização. Editora Cubo, São Paulo, pp. 84-85.

Ganders, F.R. 1976. The biology of heterostyly. New Zealand Journal of Botany 17: 607-635.

Hesse, M., Halbriter, H., Zetter, R., Weber, M., Buchner, R., Frosch-Radivo, A. \& Ulrich, S. 2009. Pollen Terminology: an illustrated handbook. SpringerWien. NewYork.

Judd, W.S., Campbell, C.S, Kellogg, E.A., Stevens, P.F. \& Donoghue, M.J. 2007. Plant systematics: a phylogenetic approach. 4th. Edn. Sunderland, Sinauer Associates, Inc.

Klitgaard, B.B. \& Lavin, M. 2005. Tribe Dalbergieae sens. lat. In: G.P. Lewis, B.D. Schrire, B.A. MacKinder \& M. Lock (eds.). Legumes of the world. Royal Botanic Gardens, Kew, pp. 307-335.

Lavin, M., Pennington, R.T., Klitgaard, B.B., Sprent, J.I., Lima, H.C. \& Gasson, P.E. 2001. The dalbergioid legumes (Fabaceae): delimitation of a pantropical monophyletic clade. American Journal of Botany 88: 503-533.

Lewis, G., Schrire, B., Mackinder, B. \& Lock, M. 2005. Legumes of the world. Royal Botanic Gardens, Kew.

Lima, L.C.P., Oliveira, M.L.A.A. \& Souza, V.C. 2015. Aeschynomene in Lista de Espécies da Flora do Brasil. Jardim Botânico do Rio de Janeiro. Available in: http:// floradobrasil.jbrj.gov.br/jabot/floradobrasil/FB22777 (access in 24-IV-2018). 
Lorscheitter, M.L. 2006. Contribuição da palinologia aos estudos filogenéticos das Angiospermas. In: J.E.A. Mariath \& R.P. Santos (org.). Os avanços da botânica no início do século XXI. Porto Alegre, pp. 43-48.

Luo, Z., Zhang, D. \& Renner, S.S. 2008. Why two kinds of stamens in buzz pollinated flowers? experimental support for Darwin's division-oflabour hypothesis. Functional Ecology 22: 794-800.

Melhem, T.S., Cruz-Barros, M.A.V., Corrêa, A.M.S., Makino-Watanabe H., Silvestre-Capelato, M.S.F. \& Gonçalves-Esteves, V.L. 2003. Variabilidade polínica em plantas de Campos do Jordão. Boletim do Instituto de Botânica 16: 1-104.

Mitra, K. \& Mondals M. 1982. Pollen morphology of exstipellate and stipellate Hedysareae (Leguminosae). Proceedings of the Indian National Science Academy 48: 755-769.

Ohashi, H. 1971. A taxonomic study of the tribe Coronulleae (Leguminosae), with a Special Reference to Pollen Morphology. Journal of the Faculty of Science, University of Tokyo 11: 25-92.

Von der Ohe, K. \& Dustmann, J.H. 1996. Identifizierung einer bisher nicht zugeordneten Pollenform in mittelamerikanischen Honigen (sog 'Cuba-Form'): Aeschynomene americana L (Leguminosae, Papilionoideae). Apidologie 27: 157-163.

Pire, S.M.L. 1974. Estudio Palinologico de la Tribu "Hedysareae" (Leguminosae). Bonpladia 3: 143-169.

Punt, W., Hoen, P.P., Blackmore, S., Nilsson, S. \& LeThomas, A. 2007. Glossary of pollen and spore terminology. Review of Palaeobotany and Palynology 143: 1-81.

Ribeiro, R.A., Lavin, M., Lemos-Filho, J.P., Mendonça Filho, C.V., Santos, F.R. \& Lovato, M.B. 2007. The genus Machaerium (Leguminosae) is more closely related to Aeschynomene sect. Ochopodium than to Dalbergia: inferences from combined sequence data. Systematic Botany 32: 762-771.
Rudd, V.E. 1955. The American species of Aeschynomene. Contributions from the U.S. National Herbarium 32: $1-172$.

Rudd, V.E. 1959. Supplementary studies in Aeschynomene, I: Series Viscidulae, including a new species and five new varieties. Journal Washington Academy of Sciences 49: 45-52.

Rudd, V.E. 1981. Aeschynomeneae (Benth.) Hutch. In: R.M. Polhill \& P.H. Raven (eds.). Advances in legume systematics. Royal Botanic Gardens, Kew, v. I, pp. 347-354.

Salgado-Labouriau, M.L. 1973. Contribuição à palinologia dos Cerrados. Academia Brasileira de Ciências, Rio de Janeiro.

Sampaio, D.S. 2005. Ontogênese floral, esporo e gametogênese em anteras de Aeschynomene falcata (Poir.) DC. e Aeschynomene sensitiva Sw. (Papilionoideae-Leguminosae). Dissertação de Mestrado, Universidade Federal do Rio Grande do Sul, Porto Alegre.

Sharma, B.D. 1968. Occurrence of 3-Zonocolpate, Diorate Pollen in Aeschynomene aspera Linn. (Leguminosae) and the Significance of Pollen Morphology in the Taxonomy of the Genus Aeschynomene Linn. Botanical Survey of India 10: 369-373.

Silva, M.J. \& Antunes, L.L.C. 2014. An update of the Brazilian species of Aeschynomene sect. Ochopodium ser. Viscidulae including a new species and a new synonym. Phytotaxa 184: 31-38.

Stanski, C., Antonio-Domingues, H., Kuniyoshi, S. \& Luz, C.F.P. 2016. Palynotaxonomy of heterostylous species of Psychotria L. (Rubiaceae). In: Boletín de la Asociación Latinoamericana de Paleobotánica y Palinología 16: 274-275.

Souza. F.C., Souza, M.A., Mendonça, C.B.F. \& GonçalvesEsteves, V. 2004. Estudos polínicos de espécies de Aeschynomeneae e Phaseoleae (Papilionoideae Leguminosae Juss.) ocorrentes nas restingas do estado do Rio de Janeiro. Arquivos do Museu Nacional do Rio de Janeiro 62: 357-366.

Vieira, S. 1981. Introdução à Bioestatística. Rio de Janeiro. 